Cite as: Pollack, J., Algeo, C. (2016) Project managers' and change managers' contribution to success, International Journal of Managing Projects in Business, 9(2), pp. 451 - 465, http://dx.doi.org/10.1108/IJMPB-09-2015-0085

\title{
Project managers' and change managers' contribution to success
}

\author{
Julien Pollack, \\ University of Technology Sydney \\ Faculty of Design, Architecture and Building \\ julien.pollack@uts.edu.au \\ PO Box 123 Broadway, 2007, Australia \\ Corresponding author \\ Chivonne Algeo \\ University of Technology Sydney \\ Faculty of Design, Architecture and Building \\ chivonne.algeo@uts.edu.au \\ PO Box 123 Broadway, 2007, Australia
}

\begin{abstract}
Purpose: Many projects involve an organisational change component. Project management and change management have the potential to jointly contribute to the delivery of organisational changes. However, there is a lack of clarity in the literature about the boundary and relationship between these disciplines. This paper explores the contribution these disciplines make to a set of project critical success factors, to understand the ways that these disciplines can most effectively work together.
\end{abstract}

Design/methodology/approach: This paper analyses data collected through an online survey, examining project managers' and change managers' perception of each disciplines' contribution to critical success factors. The survey received 455 responses.

Findings: This paper identifies the success factors that are most clearly influenced by project management and change management, and areas where practitioners of these disciplines hold significantly different perceptions of their contributions. The results have been used to rank and categorise success factors based on the influence of each discipline. This has been used to develop a risk-based questionnaire to guide the contribution of project management and change management to the mitigation of specific project risks.

Originality/value: These findings will be of use to practitioners managing organisational change projects, or projects with a significant change component. The findings will be of assistance in determining the ways in which these disciplines should work together to mitigate risks associated with specific critical success factors.

\section{Keywords}

Project management; Change management; Organisational change; Risk management; Critical success factors 
Cite as: Pollack, J., Algeo, C. (2016) Project managers' and change managers' contribution to success, International Journal of Managing Projects in Business, 9(2), pp. 451 - 465,

http://dx.doi.org/10.1108/IJMPB-09-2015-0085

\section{Introduction}

Many projects involve an organisational change component, whether it involves a need to ensure user uptake, changes to working habits, training, or facilitating the structural and cultural alignment of a project and its outcomes with the client or contracting organisation. Project Management (PM) and Change Management (CM) have been identified in a variety of research as a potentially effective combination of management techniques (PMI, 2013a; Pádár et al, 2011; Winch et al, 2012; Levasseur, 2010; Boddy \& Macbeth, 2000; Leybourne, 2006) for projects involving some aspect of organisational change. However, there is little consensus about the ways that these disciplines should work together to deliver projects (Crawford \& Nahmais, 2010; Jarocki, 2011).

These two disciplines imply significantly different perspectives on organisational activity. A reason for this difference of opinion can be found in the different traditions, backgrounds and bodies of knowledge associated with these disciplines (Lehmann, 2010; Garfein \& Sankaran, 2011). For instance, it has been identified that project managers and change managers have quite different views on the degree to which the other discipline should contribute to different project activities (Pollack \& Algeo, 2014a), and that they may perceive issues as fundamental as project success in different ways (Pollack \& Algeo, 2014b). The research presented in this paper extends this line of enquiry, by examining the ways in which these disciplines contribute to specific critical success factors, and by implication to overall project success.

\section{Literature Review}

Project success is one of the more popular topics in the project management literature. There are a great variety of academics and practitioners who have contributed to the debate about factors that influence the success of projects. Interested readers are referred to Müller and Jugdev's (2012) review of the development of research into critical success factors and the influence of seminal authors in the field. One large body of project success research focuses on isolating factors that influence the success of specific project types. For example, studies have enquired into success in defence projects (Mazur et al, 2014); Public Private Partnership projects (Zou et al, 2014; Osei-Kyei \& Chan, 2015); virtual projects (Verburg et al, 2013); events projects (Cserháti \& Szabó, 2014); mega-projects (Chang et al, 2013); World Bank projects (Ika et al, 2011; 2012); technology projects in Thailand (lamratanakul et al, 2014); projects in Brazil (Berssaneti \& Carvalho, 2015); and urban regeneration in Korea (Yu \& Kwon, 2011). Other researchers have focused on the project process, such as the acceptance of ambiguity (Hagen \& Park, 2013), the effect of risk management (de Bakker et al, 2012), or the impact of project planning (Zwikael et al, 2014) on project success.

A second broad area of enquiry into project success focuses on interpersonal factors, such as the impact of executive sponsor behaviour (Kloppenborg et al, 2014) and sponsor support (Helm \& Remington, 2005), top management support (Young \& Poon, 2013), contractor's attributes (Alzahrani \& Emsley, 2013; Ng \& Tang, 2010), leaders' values (Aronson et al, 2013), and project managers' personality types (Creasy \& Anantatmula, 2013). However, a review of the literature revealed no research that specifically enquired into the relative contribution that project management makes to project success, when compared to other associated disciplines.

This paper focuses on the roles that PM and CM have in contributing to project success, placing this research in the context of research into interpersonal factors. Although PM and $\mathrm{CM}$ are popularly used in the delivery of organisational change management projects, “... project management and change management have been, and in most cases are, sold, 
Cite as: Pollack, J., Algeo, C. (2016) Project managers' and change managers' contribution to success, International Journal of Managing Projects in Business, 9(2), pp. 451 - 465,

http://dx.doi.org/10.1108/IJMPB-09-2015-0085

practiced, and managed as two almost mutually exclusive project disciplines" (Jarocki, 2011, p. 69). PM and CM are based on significantly different theoretical backgrounds. This may be one reason for the divide between the disciplines.

The early development of PM was influenced by management approaches like Cybernetics (Urli \& Urli, 2000), Systems Engineering, and Systems Analysis (Morris, 2002), all of which are examples of hard systems thinking. Early PM was most commonly practiced in the aerospace (Morris, 2013), construction, and engineering industries, although in recent years this emphasis may be changing. PM has also typically focused on ways of using quantitative techniques to control a project budget, schedule, and the final product quality (Yeo, 1993). The practice of project management has been strongly influenced by professional associations such as the Project Management Institute and normative guides like the PMBOK Guide (PMI, 2013b).

The theoretical background of CM has, in contrast, drawn on a broad literature encompassing communication, human relations, organisational development, and strategy (Crawford \& Namais, 2010), including works by Phillips (1983) and Connor (1993). A wide variety of approaches are available to practitioners of CM (Mento et al, 2002). Readers interested in a detailed analysis of the development of $\mathrm{CM}$ are referred to Cao and McHugh (2005) for further reading. The field is arguably more diffuse than PM, which can be partly attributed to the relatively recent development of the field. CM focuses on managing the people side of change, focusing on engagement, ownership and the human and emotional aspects of change. This is a distinctly different activity to the project management process of configuration control, which is sometimes also termed change management.

Practitioners of CM are supported by professional associations, such as the Association of Change Management Professionals, and the Change Management Institute. They may come from a variety of allied disciplines, or consider themselves specialist change managers. Recognition of a specialist change manager role appears to be growing, with market acceptance of the role of change manager particularly common in Australia. The Change Management Institute conducted research into CM employment trends and found 1,344 change management positions advertised in 2014 across three markets. Of these, $60 \%$ of the positions were advertised in Australia, $35 \%$ were in the UK, and $5 \%$ were in New Zealand (CMI, 2014).

Although both PM and CM are used to deliver organisational change projects, $\mathrm{CM}$ tends to place less emphasis on controlled delivery and a means-end orientation than can be found in PM. Instead, CM tends to emphasise developing and communicating a compelling vision, aligning with organisational strategy, engaging leadership in the change process, and developing employee and leader ownership of the change. While PM has often focused on aspects of method and technique, CM typically focuses on examination of the dynamics of how organisations change (Lehmann, 2010). While a project manager may consider managing stakeholders to be one of many subsets of the larger PM process, a change manager may consider managing aspects of engagement, awareness, resistance reduction, and emotional commitment to be the central ways that change is created in an organization. Research has shown that different skills are needed to practice each of these disciplines (Alsene, 1998; Garfein \& Sankaran, 2011), suggesting that although in some cases individuals may be able to practice both disciplines, most individuals will favour one role or the other.

It appears that although different literatures and traditions may have informed the development of these disciplines, there is an increasing amount of attention on areas that are more typical of CM in PM publications (Urli \& Urli, 2000). This change can be seen in a growing emphasis on human-centred topics, such as teams, leadership and motivation 
Cite as: Pollack, J., Algeo, C. (2016) Project managers' and change managers' contribution to success, International Journal of Managing Projects in Business, 9(2), pp. 451 - 465,

http://dx.doi.org/10.1108/IJMPB-09-2015-0085

(Kloppenborg \& Opfer, 2002), and less focus on process than on people (Leybourne, 2007). Stakeholder management has also recently been included as a knowledge area in the $5^{\text {th }}$ edition of the Project Management Institute's Guide to the Project Management Body of Knowledge (PMI, 2013b), suggesting that the shift towards people-related issues in PM is also occurring in the normative literature. The divide between the PM and CM literatures appears to be reducing, and this is supported by two recent studies. Lehmann (2010) examined how communication was treated in the PM and CM literatures, while Pádár et al (2011) examined how stakeholder roles were discussed in these literatures. Both of these studies found that there were similarities between how these topics were treated by PM and CM, with Lehmann's (2010) research concluding that there was an increasing convergence between the literatures.

With respect to the management of organisational change projects, strategic alignment, user uptake, and benefits realisation, there is an "...obvious overlap between the two disciplines..." (Jarocki, 2011, p. 69). It has also been noted that there are strong similarities between project managers' and change mangers' roles (Crawford, 2011). Potentially resulting from the ambiguity about the boundary between these disciplines, other research has identified "...evidence of a degree of rivalry between Project Managers and Change Managers concerning who should be managing business change" (Crawford \& Nahmais, 2010, p. 405).

This research seeks to develop an understanding of productive ways in which these disciplines can work together in the delivery of organisational change by exploring practitioners' views about PM and CM. In particular, this research examines practitioners' views about each disciplines' influence over factors that contribute to the successful delivery of projects. This research explores the following question:

How significant is the influence of Project Management and Change Management over critical success factors, and what does this reveal about how practitioners of these disciplines should work together in practice?

Crawford \& Nahmias' (2010) research previously enquired into the relationship between PM and $\mathrm{CM}$, developing a framework for decisions about PM and CM engagement. Their framework relies on two criteria to guide engagement decisions: the level of leadership and cultural support; and the degree of behavioural change required. The research presented in this paper takes a different approach, starting from a focus on 24 factors that contribute to project success. Rockart (1979, p. 85) defined critical success factors as "...the limited number of areas in which results, if they are satisfactory, will ensure successful competitive performance ... They are the few key areas where 'things must go right' for the business to flourish". This research builds on the critical success factors presented in Fortune and White's (2006) comprehensive review of the critical success factor literature. Their research is used as a basis for understanding the ways in which project managers and change managers can work together most effectively.

\section{Research Methodology}

Data for this research was collected using an anonymous online survey. It was particularly important for this research to account for the perspectives of project managers and change managers. To encourage responses from these populations, three industry associations were approached: the Project Management Institute; the Australian Institute of Project Management; and the Change Management Institute. A link to the survey was distributed by each of these associations to their members. The researchers also used their professional networks to promote the survey, and posted links to the survey on relevant social media 
Cite as: Pollack, J., Algeo, C. (2016) Project managers' and change managers' contribution to success, International Journal of Managing Projects in Business, 9(2), pp. 451 - 465, http://dx.doi.org/10.1108/IJMPB-09-2015-0085

discussion forums. There were 455 responses to the survey. Responses were analysed using SPSS 22 statistical software.

The research presented in this paper focused on two main questions. The first of these asked respondents to identify their profession, by selecting one option from the following: "Project Manager (including junior, senior, committee and sponsor positions)"; Change Manager (including junior, senior, committee and sponsor positions)"; or "Other". Of the survey population, $56 \%$ were project managers (256); $14 \%$ were change managers (63); and $30 \%$ (136) selected "Other" or gave an invalid response. Invalid responses and "Other" responses have been excluded from the analysis presented here.

The second question asked respondents to rate project managers' and change managers' contribution to a list of critical success factors: "From your general experience, how significant is the influence of Change Management (CM) and Project Management (PM) personnel in affecting the following?" The 24 success factors identified by Fortune and White (2006) followed this question, and the survey asked respondents to use seven-point Likert scale (1: No influence, 7: Very great influence) to separately rate each discipline's influence over each success factor. It is acknowledged that the use of Fortune and White's (2006) success factors may have introduced a PM, rather than a CM, bias to the research, but as no comparable CM success factors were apparent in the literature this bias seemed to be unavoidable.

\section{Comparative influence over success criteria}

A comparative ranking was developed using the research data. It demonstrates the contribution that each discipline makes to Fortune and White's (2006) success factors. First, the responses were separated into two groups: those made by project managers; and those made by change managers. Averages of these responses were then taken, and the results were then normalised to account for a smaller number of change managers in the respondent population. The difference between the normalised results for responses for change managers' and project managers' contribution to these success factors was then calculated. This result was then used to rank the success factors from those that were seen as more strongly influenced by project managers, to those that were more strongly influenced by change managers (Figure 1). 
Cite as: Pollack, J., Algeo, C. (2016) Project managers' and change managers' contribution to success, International Journal of Managing Projects in Business, 9(2), pp. 451 - 465, http://dx.doi.org/10.1108/IJMPB-09-2015-0085

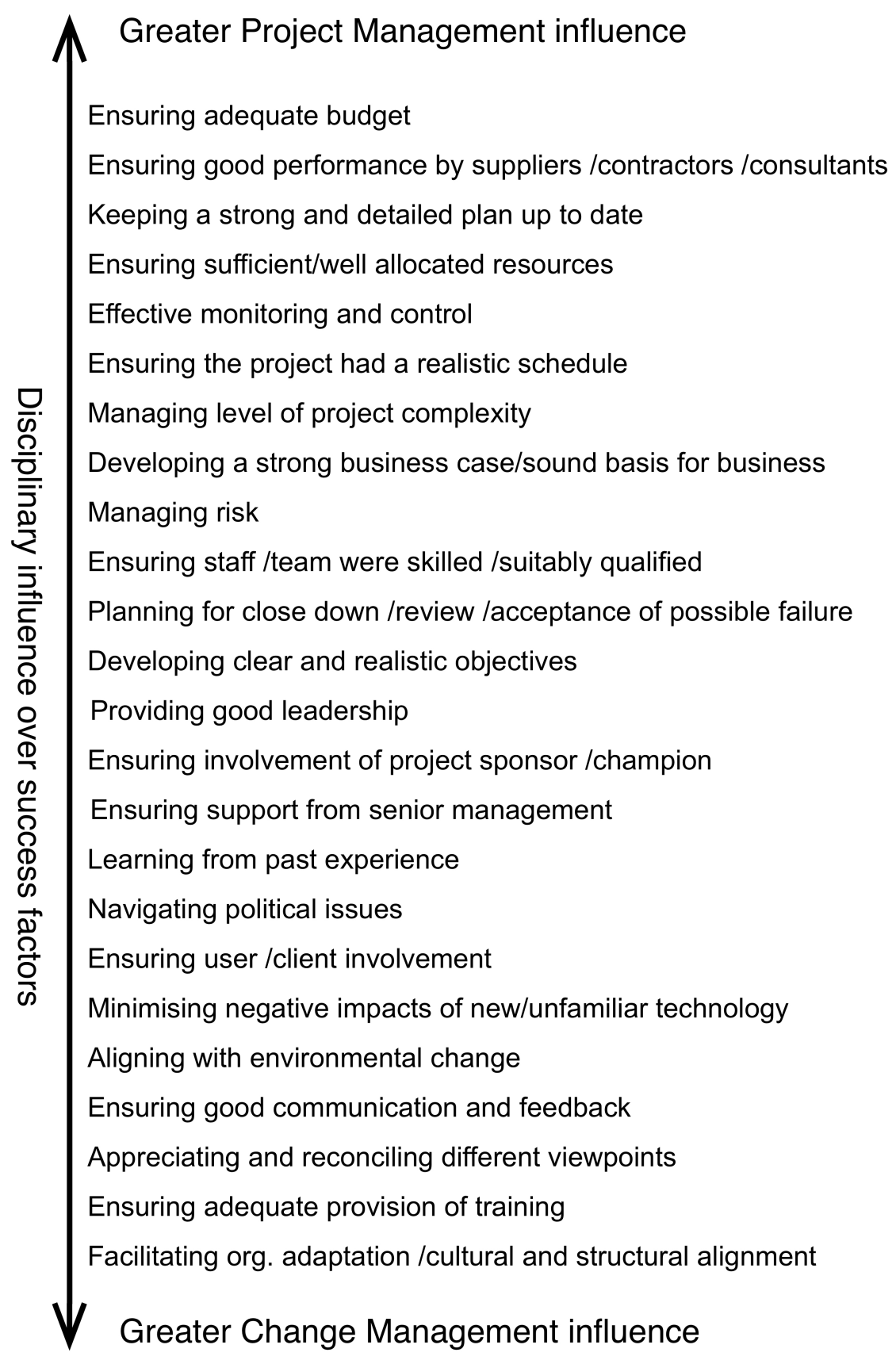

Figure 1: A comparative ranking of disciplinary contribution to project success factors

\section{Do these disciplines perceive their contribution differently?}

The data was analysed using the Mann-Whitney $U$ Test to understand whether there were differences in how the project managers and change managers were rating each disciplines' influence over the 24 success factors. The Mann-Whitney U Test identifies significant differences between the populations' response distributions. It was useful in identifying areas where the respondents agreed or disagreed about how significantly one of these disciplines contributed to specific success factors. Those success factors for which it was possible to reject the null hypothesis that the distribution of the results was the same for the project managers and the change managers $(p<0.01)$ are listed in Table 1. 
Cite as: Pollack, J., Algeo, C. (2016) Project managers' and change managers' contribution to success, International Journal of Managing Projects in Business, 9(2), pp. 451 - 465,

http://dx.doi.org/10.1108/IJMPB-09-2015-0085

\begin{tabular}{|c|c|c|c|c|c|}
\hline Discipline & Question & Sig. & $\begin{array}{l}\text { Median } \\
\text { PM's } \\
\text { response }\end{array}$ & $\begin{array}{l}\text { Median } \\
\text { CM's } \\
\text { response }\end{array}$ & $\mathbf{n}$ \\
\hline \multirow{5}{*}{$\begin{array}{l}\text { Differences of } \\
\text { opinion about } \\
\text { project } \\
\text { manager } \\
\text { influence }\end{array}$} & $\begin{array}{l}\text { Ensuring good communication } \\
\text { and feedback }\end{array}$ & .000 & 7 & 6 & 317 \\
\hline & Ensuring user / client involvement & .001 & 6 & 6 & 315 \\
\hline & $\begin{array}{l}\text { Facilitating organisational } \\
\text { adaptation / cultural and structural } \\
\text { alignment }\end{array}$ & .000 & 6 & 5 & 315 \\
\hline & $\begin{array}{l}\text { Appreciating and reconciling } \\
\text { different viewpoints }\end{array}$ & .000 & 7 & 6 & 317 \\
\hline & $\begin{array}{l}\text { Aligning with environmental } \\
\text { changes }\end{array}$ & .005 & 6 & 6 & 317 \\
\hline \multirow{7}{*}{$\begin{array}{l}\text { Differences of } \\
\text { opinion about } \\
\text { change } \\
\text { manager } \\
\text { influence }\end{array}$} & $\begin{array}{l}\text { Ensuring support from senior } \\
\text { management }\end{array}$ & .002 & 6 & 7 & 305 \\
\hline & $\begin{array}{l}\text { Ensuring good communication } \\
\text { and feedback }\end{array}$ & .000 & 6 & 7 & 305 \\
\hline & Ensuring user / client involvement & .003 & 6 & 7 & 304 \\
\hline & Providing good leadership & .003 & 6 & 7 & 303 \\
\hline & $\begin{array}{l}\text { Ensuring involvement of project } \\
\text { sponsor / champion }\end{array}$ & .000 & 6 & 7 & 303 \\
\hline & Navigating political issues & .002 & 6 & 7 & 302 \\
\hline & $\begin{array}{l}\text { Managing level of project } \\
\text { complexity }\end{array}$ & .000 & 5 & 6 & 300 \\
\hline
\end{tabular}

Table 1: Success factors rated significantly differently by the disciplines

There was a significant difference at $(p<0.01)$ in how the two groups responded to 12 of the 48 questions, and 23 of the 48 questions at $(p<0.05)$. This result lends weight to the argument that project managers and change managers perceive aspects of project implementation in significantly different ways. For each of the factors where there was a significant difference in the response distribution, each discipline rated their influence over the factors as higher than they rated the influence of the other discipline. It is interesting to note that both disciplines rated their influence over ensuring good communication and feedback, and ensuring user / client involvement significantly higher than they rated the other disciplines' influence. These results suggest that there may be substantial disagreement between the disciplines about how responsibility for these factors should be allocated.

The project managers rated their influence over the following factors significantly higher than the change managers did: facilitating organisational adaptation/cultural and structural alignment (23.8\%); appreciating and reconciling different viewpoints (12.7\%); and aligning with environmental changes $(12.7 \%)$. In each of these cases, there was a significant number of change managers who did not consider that project managers had much influence over these factors, and the numbers in brackets following each factor above represent the percentage of change managers answering that project managers had little or no influence over these factors, respectively (response of 1-3 on the Likert scale).

The change managers rated their influence over the following factors significantly higher than the project managers did: ensuring support from senior management (6.3\%); providing good leadership (7.9\%); ensuring involvement of project sponsor/champion (11.3\%); 
Cite as: Pollack, J., Algeo, C. (2016) Project managers' and change managers' contribution to success, International Journal of Managing Projects in Business, 9(2), pp. 451 - 465,

http://dx.doi.org/10.1108/IJMPB-09-2015-0085

navigating political issues (8.6\%); and managing the level of project complexity (13.3\%). In each of these cases, there was a significant number of project managers who did not consider that change managers had much influence over these factors, and the numbers in brackets following each factor above represent the percentage of project managers answering that change managers had little or no influence over these factors, respectively (response of 1-3 on the Likert scale).

Review of these results suggests that there are elements within both the PM and CM communities that lack confidence in the other discipline's ability to communicate effectively, and to involve the users and client in the project process. This is particularly problematic for $\mathrm{CM}$ given how central these issues are to the field. Change managers appear to lack confidence in project managers' ability to align a project with the organisation and the changing environment. Although PM may be developing to take greater account of these factors, this result is less surprising given the hard systems thinking origins of project management, and the tendency to assume that once defined, deviation from determined specifications and success criteria should be minimised. Project managers appear to lack confidence in change managers' abilities to manage senior management and the politics associated with a project. In addition, project managers did not rate change managers' abilities to lead projects and guide them through complexity particularly highly. This can be related to the findings in previous research (Pollack \& Algeo, 2014b) that suggests that project managers tend to think that managerial responsibility for a project should rest with project managers, and that change managers should play a supporting role to PM direction.

\section{Discussion: The relative need for project management and change management}

One approach to addressing the question of how, and in which ways, project managers and change managers should work together is by adopting a risk-based perspective. The concept of risk management has been used in combination with the concept of critical success factors in a variety of previous research (e.g. Hwang et al, 2013; Chou \& Pramudawardhani, 2015). Besner and Hobbs (2013, p. 233) have commented that the links between project success and risk management are far from clearly understood. However, critical success factors can provide a way of guiding risk analysis. Wang (2015, p. 686) has found that risks can arise when critical success factors are not adequately addressed, and that project sponsors should change the ways they managed risk to selectively address critical success factors. The research presented here builds on this link between risk management and critical success factors. We propose that critical success factors can be used as a basis for risk analysis. If the factors which are critical for the success of a project are not given due attention during delivery, if particular factors are more uncertain, or if they have an unusually large impact, these factors could represent areas of greater risk to achieving project success.

By using critical success factors as the basis of a risk assessment, it is possible to develop an understanding of the ways in which project mangers and change managers can most effectively contribute to project success. In Figure 2, each of the critical success factors used in the analysis above has been used to represent a possible area of risk. These have been categorised into those that are highly influenced by project managers (1) and those that are most influenced by change managers (2). Risks placed at the centre top of Figure 2 are shared risks (3) and should be the responsibility of whoever is in a position of authority and influence in a project, regardless of their disciplinary background. 
Cite as: Pollack, J., Algeo, C. (2016) Project managers' and change managers' contribution to success, International Journal of Managing Projects in Business, 9(2), pp. 451 - 465,

http://dx.doi.org/10.1108/IJMPB-09-2015-0085

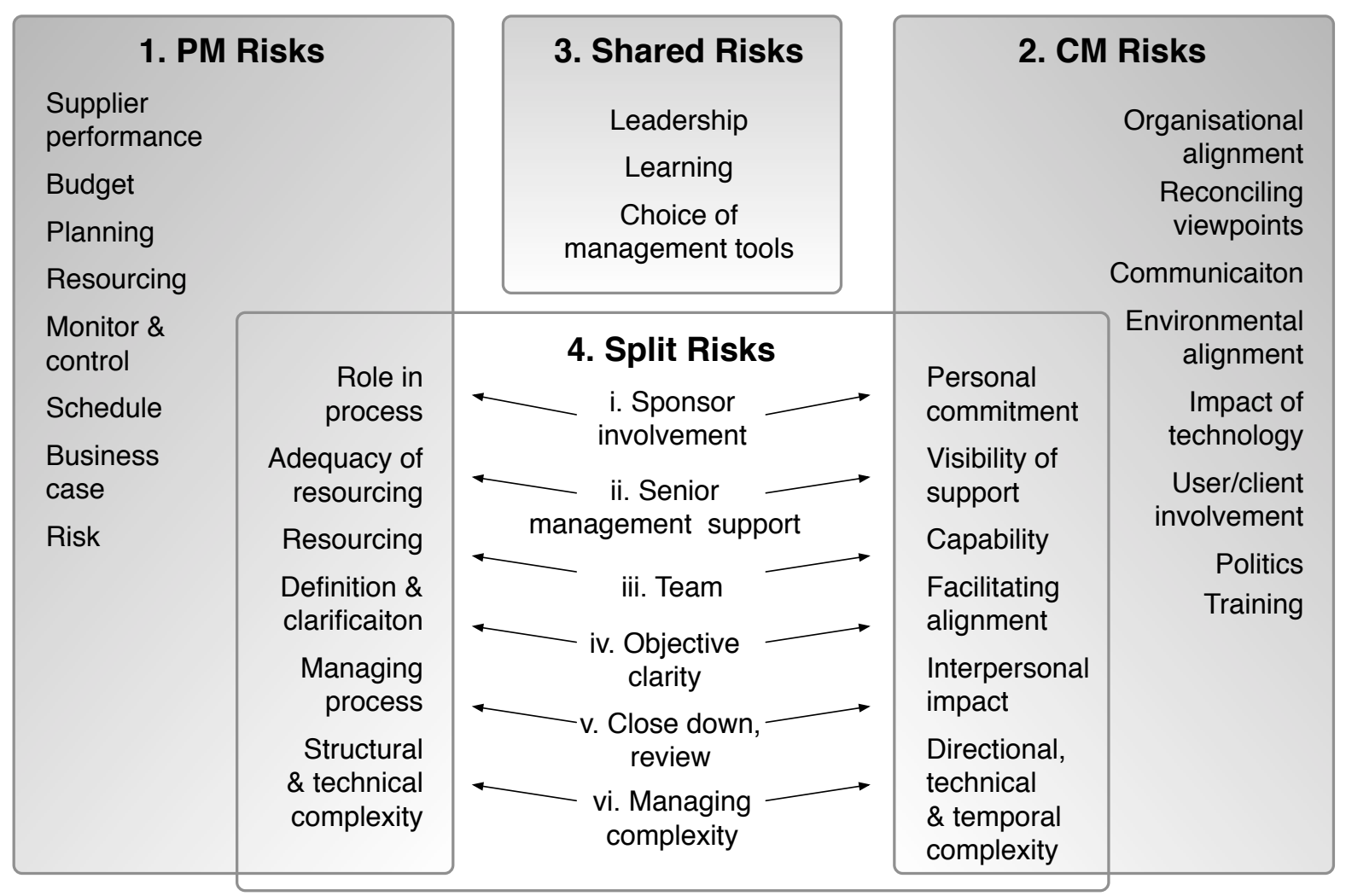

Figure 2. Sources of risk and disciplinary contribution

The risks categorised as split risks (4) in Figure 2 were less easily categorised as within the province of PM or CM. Review of these risks revealed that it was possible to interpret them quite differently, depending on whether they were being reviewed from a PM or a CM perspective. Taking (i) Sponsor Involvement as an example, both PM and CM have a role in making sure that a sponsor is involved in a project. However, while a project manager may focus on involving the sponsor in the formal decision making process, a change manager may focus on ensuring the sponsor's personal commitment to the project. These disciplines also bring a different emphasis to (ii) Senior Management Support. Project managers may focus on the role that senior management play in securing adequate resources for a project, while change managers may focus more on the way that the visibility of senior management support adds legitimacy to a change. Project managers will focus on securing the best human resources for their team (iii), while a change manager may focus more on ensuring the team has adequate training and commitment. The disciplines may also respond to objective clarity (iv) in different ways. While project managers will traditionally focus on the need for objectives that are unambiguously and clearly defined, change managers may focus on the need to facilitate the alignment of key stakeholders to create and adapt the objectives of a project. Project managers may focus on managing the process of review and project close down (v), while a change manager will focus more on the interpersonal impacts of shutting a project down.

With respect to the risk of managing complexity in Figure 2 (vi), it was possible to clarify the different perspectives through reference to four different types of project complexity (Remington \& Pollack, 2007). The perception of structural complexity on a project is related to the sheer quantity of interconnected elements. The individual parts of a project may be separately simple, but the quantity of elements can result in unperceived vicious and virtuous feedback loops, emergent risks, and rapid phase changes as consequences cascade through dependencies. Structural complexity is typically seen on large projects. PM 
Cite as: Pollack, J., Algeo, C. (2016) Project managers' and change managers' contribution to success, International Journal of Managing Projects in Business, 9(2), pp. 451 - 465 ,

http://dx.doi.org/10.1108/lJMPB-09-2015-0085

tools and techniques often attempt to address these issues using a reductionist emphasis on breakdown and control. Technical complexity arises in projects where it is clear what has to be done, but not how it can be achieved. Technical complexity results from ambiguity in the many interdependent design solutions that may be reached. PM tends to address this issue by focusing on managing the solution design, while CM tends to address technical complexity by focusing on the impact of new technologies on users of the project outputs. Directional complexity arises in projects where it is not clear what has to be done, either through lack of definition or conflict amongst stakeholders, and as CM places some emphasis on reconciling viewpoints, change managers may be of assistance in resolving this type of project complexity. Temporal complexity is found in projects that anticipate significant changes to the environment outside the project control, but must continue towards delivery despite the expectation of change. The $\mathrm{CM}$ emphasis on organisational and environmental alignment could be of benefit in addressing this type of complexity.

Projects are time critical endeavours, and as such it is not always possible to take extensive action to address all possible critical success factors. It is suggested that a risk-based approach be used to understand where and in which ways project managers and change managers can most effectively work together. Risk analysis can be used as a way of identifying which success factors are likely to be an issue in a particular organisation or project, and the categories of critical success factors identified above (Figure 2) can be used as a way of determining the ways in which PM and CM can contribute to project success.

In projects where no significant impact is expected from any of the risks identified as CM risks (Figure 2) the need for a change manager is less significant. CM related issues could be managed by occasional CM support, or by a project manager who is comfortable with $\mathrm{CM}$. The inverse should also be true. In projects where no significant impact is expected from any of the risks identified in Figure 2 as PM risks, but it is anticipated that there will be significant $\mathrm{CM}$ related risks, there would be less need for a project manager to manage the project. The project could then be managed by a change manager with some PM competencies, with potential support from project administrative staff. In cases where significant risks are expected at both ends of this spectrum, then a cooperative arrangement will need to be reached, and the framework in Figure 2 could provide a basis for negotiating a division of responsibility.

A checklist and rating system has been included as an appendix to this paper, which could be used as the basis for guiding overall project manager and change manager responsibility for a project, and identifying areas where typical PM or CM support would be of benefit. Factors that were determined to be the shared responsibility of PM and CM personnel were left out of the checklist, as risks associated with these factors would not be of benefit in distinguishing between project managers' and change managers' responsibility. Factors were varyingly weighted in the checklist, based on the responses to the survey instrument. Review of the checklist will reveal that there is some bias towards PM, with a greater weighting given to more of the PM related success factors. This can be attributed to the use of Fortune and White's (2006) success factors as the basis for this research; factors that were developed for information systems project management without explicit regard for organisational change management. Future research into this topic may consider including an initial step involving the development of a specific set of critical success factors related to the management of organisational change. Future research could also use data collected during organisational change projects to understand the lived practicalities of how these disciplines contribute to the success of organisational change projects.

\section{Conclusion}


Cite as: Pollack, J., Algeo, C. (2016) Project managers' and change managers' contribution to success, International Journal of Managing Projects in Business, 9(2), pp. 451 - 465,

http://dx.doi.org/10.1108/IJMPB-09-2015-0085

This paper has presented the analysis of survey results enquiring into project managers' and change managers' influence over 24 critical success factors. Survey responses were used to develop an ordered ranking of critical success factors, from those more clearly influenced by project management, to those more clearly influenced by change management. Analysis of the survey results then identified factors that were regarded significantly differently by the change managers and project managers who responded to the survey. Significant differences were apparent in almost half of the questions asked, suggesting that project managers and change managers perceive aspects of project implementation very differently. In particular, there was a tendency for each discipline to rate their contribution to ensuring good communication and feedback, and ensuring user / client involvement significantly higher than they rated the other disciplines' influence. These issues are more likely to be where conflict may arise between the disciplines. These findings should be of concern for change managers, given the significance of these topics to their discipline. This suggests that further work is needed to ensure that project managers are aware of what change management is and the role it can play in the success of organisational change projects.

Both disciplines have a claim to the management and delivery of organisational change projects. However, there is a lack of clarity about how the disciplines should work together to reduce risks on projects. The research findings were used to group the critical success factors into those that were most influenced by project management, those most influenced by change management, and those that were the responsibility of whoever was in a leadership position, regardless of their discipline. The categorisation and comparative ranking were used to develop a questionnaire for use as a supplement to risk analysis processes. It was designed to help practitioners determine project manager and change manager responsibility for aspects of project delivery based on where significant risks are expected in the project. Using this as a way of negotiating project manager and change manager responsibility for aspects of organisational change project delivery should help to ensure that the skills associated with these disciplines are applied as effectively as possible.

\section{Acknowledgement}

This paper is based on research presented at the [REMOVED FOR BLIND REVIEW] conference. The authors wish to thank the conference organisers and attendees for their feedback, which was of assistance in the development of this paper.

\section{References}

Alsene, E. (1998), "Internal Changes and Project Management Structures within Enterprises", International Journal of Project Management, Vol. 17, pp. 367-76.

Alzahrani, J. and Emsley, M. (2013), "The impact of contractors' attributes on construction project success: A post construction evalaution", International Journal of Project Management, Vol. 31, pp. 313-322.

Aronson, Z., Shenhar, A. and Patanakul, P. (2013), "Managing the Intangible Aspects of a Project: The Affect of Vision, Artifacts, and Leader Values on Project Spirit and Success in Technology-Driven Projects", Project Management Journal, Vol. 44, No. 1, pp. 35-58.

Bernnaneti, F. and Carvalho, M. (2015), "Identification of variables that impact project success in Brazilian companies", International Journal of Project Management, Vol. 33, pp. 638-649. 
Cite as: Pollack, J., Algeo, C. (2016) Project managers' and change managers' contribution to success, International Journal of Managing Projects in Business, 9(2), pp. 451 - 465, http://dx.doi.org/10.1108/IJMPB-09-2015-0085

Besner, C. and Hobbs, B. (2013) "The paradox of risk management; a project management practice perspective", International Journal of Managing Projects in Business, Vol. 5 No. 2, pp. 230-247.

Boddy, D. and Macbeth, D. (2000), "Prescriptions for Managing Change: A Survey of Their Effects in Projects to Implement Collaborative Working between Organisations," International Journal of Project Management, Vol. 18, pp. 297-306.

Cao, G. and McHugh, M. (2005), "A Systemic View of Change Management and Its Conceptual Underpinnings," Systemic Practice and Action Research, Vol. 18, pp. 475490.

Chang, A., Chih, Y., Chew, E. and Pisarski, A. (2013), "Reconceptualising mega project success in Australian Defence: Recognising the importance of value co-creation", International Journal of Project Management, Vol. 31, No. 8, pp. 1139-1153.

Chou, J. and Pramudawardhani, D. (2015) "Cross-country comparisons of key drivers, critical success factors and risk allocation for public-private partnership projects", International Journal of Project management, Vol. 33, pp. 1136-1150.

Change Management Institute (2014) "CMI Employment Study", Available online at https://www.change-managementinstitute.com/sites/default/files/CMI\%20Change\%20Management $\% 20$ Employment $\% 20$ Study\%202014_1.pdf, accessed 5/11/2015.

Connor, D. (1993), Managing at the Speed of Change. Random House.

Crawford, L. and Nahmais, A. (2010), "Competencies for Managing Change," International Journal of Project Management, Vol. 28, pp. 405-12.

Crawford, L. (2011), "Adding Change Implementation to the Project Manager's Toolkit," In Proceedings of the Annual Project Management Australia Conference (PMOz): Project Management at the Speed of Light, Sydney, NSW, 2-5 August, 2011.

Creasy, T. and Anantatmula, V. (2013), "From Every Direction-How Personality Traits and Dimensions of Project Managers Can Conceptually Affect Project Success", Project Management Journal, Vol. 44, No. 6, pp. 36-51.

Cserháti, G. and Szabó, L. (2014), "The relationship between success criteria and success factors in organisational event projects", International Journal of Project Management, Vol. 32, pp. 613-624.

de Bakker, K., Boonstra, A. and Wortmann, H. (2012), "Risk managements' communicative effects influencing IT project success", International Journal of Project Management, Vol. 30, pp. 444-457.

Fortune, J. and White, D. (2006), "Framing of project critical success factors by a systems model", International Journal of Project Management, Vol. 24, pp. 53-65.

Garfein, S. J. and Sankaran, S., (2011), "Work Preferences of Project and Program Managers, Change Managers and Project Team Members: The Importance of Knowing the Difference," In PMI Global Congress, Dallas, Texas, 22-25 October, 2011. 
Cite as: Pollack, J., Algeo, C. (2016) Project managers' and change managers' contribution to success, International Journal of Managing Projects in Business, 9(2), pp. 451 - 465, http://dx.doi.org/10.1108/IJMPB-09-2015-0085

Hagen, M. and Park, S. (2013), "Ambiguity Acceptance as a Function of Project Management: A New Critical Success Factor", Project Management Journal, Vol. 44, No. 2, pp. 52-66.

Helm, J. and Remington, K. (2005), "Effective Project Sponsorship: An evaluation of the the role of the executive sponsor in complex infrastructure projects by senior project managers", Project Management Journal, Vol. 36, No. 3, pp. 51-61.

Hwang, B., Zhao, X. and Gay, M. (2013), "Public private partnership projects in Singapore: Factors, critical risks and preferred risk allocation from the perspective of contractors", International Journal of Project Management, Vol. 31, pp. 424-433.

lamratanakul, S., Badir, Y., Siengthai, S. and Skukhotu, V. (2014), "Indicators of best practices in technology product development projects: Prioritizing critical success factors", International Journal of Managing Projects in Business, Vol. 7, No. 4, pp. 602623.

Ika, L., Diallo, A. and Thuillier, D. (2011), "The empirical relationship between success factors and dimensions", International Journal of Managing Projects in Business, Vol. 4, No. 4, pp. 711-719.

Ika, L., Diallo, A. and Thuillier, D. (2012), "Critical success factors for World Bank projects: An empirical investigation", International Journal of Project Management, Vol. 30, pp. 105-116.

Jarocki, T. (2011), The Next Evolution - Enhancing and Unifying Project and Change Management, San Francisco: Brown and Williams.

Kloppenborg, T. and Opfer, W. (2002), "The Current State of Project Management: Trends, Interpretations, and Predictions," Project Management Journal, Vol. 33, No. 2, pp. 518.

Kloppenborg, T., Tesch, D. and Manolis, C. (2014), "Project Success and Executive Sponsor Behaviors: Empirical Life Cycle Stage Investigations", Project Management Journal, Vol. 45, No. 1, pp. 9-20.

Lehmann, V. (2010), "Connecting Changes to Projects Using A Historical Perspective: Towards Some New Canvases for Researchers," International Journal of Project Management, Vol. 28, pp. 328-38.

Levasseur, R. (2010), "People Skills: Ensuring Project Success - A Change Management Perspective," Interfaces, Vol. 40, No. 2, pp. 159-162.

Leybourne, S. (2006), "Improvisation within the Project Management of Change: Some Observations from UK Financial Services," Journal of Change Management, Vol. 6, No. 4, pp, 365-81.

Leybourne, S. (2007), "The Changing Bias of Project Management Research: A Consideration of the Literatures and an Application of Extant Theory," Project Management Journal, Vol. 38, No. 1, pp. 61-73. 
Cite as: Pollack, J., Algeo, C. (2016) Project managers' and change managers' contribution to success, International Journal of Managing Projects in Business, 9(2), pp. 451 - 465, http://dx.doi.org/10.1108/IJMPB-09-2015-0085

Mazur, A., Pisarski, A., Chang, A. and Ashkanasy, N. (2014), "Rating defence major project success: The role of personal attributes and stakeholder relationships", International Journal of Project Management, Vol. 32, pp. 944-957.

Mento, A., Jones, R. and Dirndorfer, W. (2002), "A change management process: Grounded in both theory and practice," Journal of Change Management, Vol. 3, No. 1, pp. 45-59.

Morris, P. (2002), "Science, objective knowledge, and the theory of project management," Proceedings of the ICE - Civil Engineering, Vol. 150, No. 2, pp. 82-90.

Morris, P. (2013), "Reconstructing Project Management Reprised: A Knowledge Perspective," Project Management Journal, Vol. 44, No. 5, pp. 6-23.

Müller, R. and Jugdev, K. (2012), "Critical success factors in projects Pinto, Slevin, and Prescott - the elucidation of project success", International Journal of Managing Projects in Business, Vol. 5, No. 4, pp. 757-775.

$\mathrm{Ng}, \mathrm{S}$. and Tang, Z. (2010), "Labour-intensive construction sub-contractors: Their critical success factors", International Journal of Project Management, Vol. 28, pp. 732-740.

Osei-Kyei, R. and Chan, A. (2015), "Review of studies on the Critical Success Factors for Public-Private Partnership (PPP) projects from 1990 to 2013", International Journal of Project Management, In Press.

Pádár, K., Pataki, B. and Sebestyen, Z. (2011), "A comparative analysis of stakeholder and role theories in project management and change management," International Journal of Management Cases, Vol. 14, pp. 252-260.

Phillips, J. (1983), "Enhancing the effectiveness of organizational change management," Human Resource Management, Vol. 22, No. 1-2, pp. 183-99.

Pollack, J. and Algeo, C., (2014), "A comparison of project managers and change manager involvement in organizational change project activities and stages," Journal of Modern Project Management, Vol. 2, No. 2, pp: 8-17.

Project Management Institute (PMI) (2013a), Managing Change in Organizations: A Practice Guide. Newtown Square, Project Management Institute.

Project Management Institute (PMI) (2013b), A Guide to the Project Management Body of Knowledge, $5^{\text {th }}$ Edition. Newtown Square, Project Management Institute.

Remington, K. and Pollack, J. (2007), Tools for Complex Projects, Gower, Aldershot.

Rockart, J. (1979), "Chief executived define their own data needs", Harvard Business Review, March-April, pp. 81-93.

Urli, B. and Urli, D. (2000), "Project Management in North America, Stability of the Concepts," Project Management Journal, Vol. 31, pp. 33-43.

Verburg, R., Bosch-Sitjtsema, P. and Variainen, M. (2013), "Getting it done: Critical success factors for project managers in virtual work settings", International Journal of Project Management, Vol. 31, pp. 68-79. 
Cite as: Pollack, J., Algeo, C. (2016) Project managers' and change managers' contribution to success, International Journal of Managing Projects in Business, 9(2), pp. 451 - 465, http://dx.doi.org/10.1108/IJMPB-09-2015-0085

Wang, Y. (2015) "Evolution of public-private partnership models in American toll road development: Learning based on public institutions' risk management", International Journal of Project Management, Vol. 33, pp. 684-696.

Winch, G., Meunier, M., Head, J. and Russ, K. (2012), "Projects as the content and process of change: The case of the health safety laboratory," International Journal of Project Management, Vol. 20, pp. 141-152.

Yeo, K.T. (1993), "Systems thinking and project management - time to reunite," International Journal of Project Management, Vol. 11, pp. 111-117.

Yu, J. and Kwon, H. (2011), "Critical success factors for urban regeneration projects in Korea”, International Journal of Project Management, Vol. 29, pp. 889-899.

Young, R. and Poon, S. (2013), "Top management support-almost always necessary and sometimes sufficient for success: Findings from a fuzzy set analysis”, International Journal of Project Management, Vol. 31, pp. 943-957.

Zou, W., Kumaraswamy, M., Chung, J. and Wong, J. (2014), "Identifying the critical success factors for relationship management in PPP projects", International Journal of Project Management, Vol. 32, pp. 265-274.

Zwikael, O. Pathak, R., Singh, G. and Ahmed, S. (2014), "The moderating effect of risk on the relationship between planning and success", International Journal of Project Management, Vol. 32, pp. 435-441.

\section{Appendix - Checklist for guiding PM and CM involvement}

How likely are the following risks to become barriers to project success:

\begin{tabular}{|c|c|c|c|c|l|}
\hline \multicolumn{7}{|c|}{$\begin{array}{l}\text { Low } \\
\text { risk }\end{array}$} & \multicolumn{3}{|c|}{$\begin{array}{l}\text { High } \\
\text { risk }\end{array}$} & Risk \\
\hline $\mathbf{0}$ & $\mathbf{2}$ & $\mathbf{4}$ & $\mathbf{6}$ & $\mathbf{8}$ & \\
\hline & & & & & Insufficient budget to complete the project \\
\hline & & & & & Poor supplier performance \\
\hline & & & & & Lack of a detailed and realistic project plan \\
\hline & & & & & Insufficient or poorly allocated resourcing \\
\hline & & & & & Inability to accurately monitor and control progress \\
\hline & & & & & Lack of an agreed and realistic schedule \\
\hline & & & & & Difficulty managing the many elements in play at once \\
\hline & & & & & An unproven technology creating unforseen problems \\
\hline & & & & & Lack of a sound business case for the project \\
\hline & & & & & Risks not identified, assessed and managed \\
\hline & & & & & Adequately experienced human resources not available \\
\hline & & & & & Lack of progress review and project termination processes \\
\hline
\end{tabular}

\begin{tabular}{|l|l|l|l|l|l|}
\hline $\mathbf{0}$ & $\mathbf{1}$ & $\mathbf{2}$ & $\mathbf{3}$ & $\mathbf{4}$ & $\mathbf{R}$ isk \\
\hline & & & & & Goals not clearly defined early in the project process \\
\hline & & & & & Sponsors not involved in the decision making process \\
\hline & & & & & Inconsistent of absent senior management support for resourcing \\
\hline
\end{tabular}

The PM risk rating is the sum of the scores above 
Cite as: Pollack, J., Algeo, C. (2016) Project managers' and change managers' contribution to success, International Journal of Managing Projects in Business, 9(2), pp. 451 - 465,

http://dx.doi.org/10.1108/IJMPB-09-2015-0085

\begin{tabular}{|c|c|c|c|c|c|}
\hline \multicolumn{6}{|r|}{ Change Management Risks } \\
\hline \multicolumn{2}{|c|}{$\begin{array}{l}\text { Low } \\
\text { risk }\end{array}$} & \multicolumn{3}{|c|}{$\begin{array}{r}\text { High } \\
\text { risk }\end{array}$} & \multirow[t]{2}{*}{ Risk } \\
\hline $\mathbf{0}$ & 2 & 4 & 6 & 8 & \\
\hline & & & & & Cultural conflict within or between organisations involved \\
\hline & & & & & Users do not adapt to new ways of working \\
\hline
\end{tabular}

\begin{tabular}{|l|l|l|l|l|l|}
\hline $\mathbf{0}$ & $\mathbf{1}$ & $\mathbf{2}$ & $\mathbf{3}$ & $\mathbf{4}$ & Risk \\
\hline & & & & & Organisational culture prohibits project termination even where warranted \\
\hline & & & & & Goal definition only accounts for a limited range of perspectives \\
\hline & & & & & The sponsor not acting as an effective project champion \\
\hline & & & & & Senior management do not visibly support the project \\
\hline & & & & & \begin{tabular}{l} 
The project is subject to political instability \\
\hline
\end{tabular} \\
\hline & & & & & Users not involved or considered in the development process \\
\hline & & & & & Uners of project outputs will be unfamiliar with the technology \\
\hline & & & & & Insufficient communication, engagement and feedback \\
\hline & & & & & Not considering important viewpoints in the project process \\
\hline & & & & & Project team / users not adequately trained to meet project demands \\
\hline
\end{tabular}

The CM risk rating is the sum of the scores above

PM score > 70: The risks identified on the project involve a significant number that relate to factors that project managers have influence over.

- $\quad$ CM score 0 - 19: The project does not appear to involve many risks that relate to factors that change managers have influence over. Overall responsibility for the project should rest with PM.

- $\quad$ CM score 20 - 39: The project involves CM risks. Overall responsibility for the project should rest with PM. However, CM personnel should be involved to address highly ranked CM risks.

CM score > 40: The risks identified on the project involve a significant number that relate to factors that change managers have influence over.

- PM score $0-35$ : The project does not appear to involve many risks that relate to factors that project managers have influence over. Consideration should be given to overall responsibility for the project resting with $\mathrm{CM}$.

- PM score 36 - 69: The project involves PM risks. Consideration should be given to overall responsibility for the project resting with $\mathrm{CM}$, with $\mathrm{PM}$ personnel involved to address highly ranked PM risks.

PM score $>=70$ and CM score $>=40$ : The project involves significant risk. Shared accountability for risk management between $\mathrm{PM}$ and $\mathrm{CM}$ personnel should be considered. 